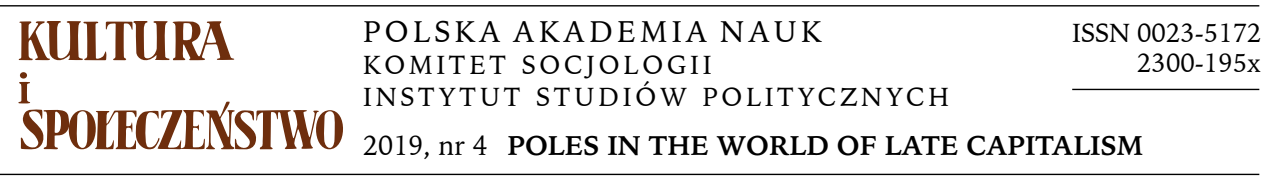
$\begin{array}{llllllll}\text { A } & \text { R } & \text { T } & \text { I } & \text { C } & \text { L } & \text { E } & \text { S }\end{array}$
A $\quad \mathrm{N} \quad \mathrm{D}$
E $\quad S \quad S \quad A \quad Y \quad S$

KAMILA BIAŁY

Institute of Sociology, University of Lodz

\title{
POSTMODERNITY IN CORPORATE BIOGRAPHIES: THE PERSPECTIVE OF RELATIONAL EPISTEMOLOGY*
}

\section{INTRODUCTION: THE EPISTEMOLOGICAL PERSPECTIVE}

Our attempt to use an epistemology other than the dominant ones in sociology (cf. below) results from the fact that the non-dualist perspective enables us to capture certain specificities of the subject within the postmodern order, that is, the epistemology of Gestalt psychotherapy (Perls, Hefferline, Goodman 1951 and contemporary developments and transformations in: Bloom 2009, Spagnuolo Lobb 2011; Francesetti 2016). This applies especially to the understanding of the self, which is (1) embodied (the phenomenological aspect), (2) embedded in the social environment (the social aspect), and (3) as such constitutes a structured phenomenological process of experience and contact with others. The emphasis here

\footnotetext{
Correspondence address: email: kamila.bialy@uni.lodz.pl; ORCID: 0000-0003-4933$-3570$

* This paper is the result of the research project Poles in the World of Late Capitalism: Changes of Biographical Processes in Terms of Professional Careers, Social Relations and Identity at the Time of System Transformation in Poland. The project was carried out in the Institute of Sociology, University of Lodz, in 2014-2018, and was financed by the Polish National Science Centre (NCN) within the OPUS scheme (grant no.: UMO-2013/11/B/HS6/01473). Members of the research team were as follows: Andrzej Piotrowski (head), Kamila Biały, Marcin Gońda, Karol Haratyk and Anna Rosińska.
} 
is placed on the fluid, constantly changing process of the interpenetrating, organising, and reorganising aspects of the "I" and "we" in the field of the self and world. Although, (4) the self also has its own aspect of continuity, consolidation, and identity sustainability, in the process of contacting, or of synthesising experience, or of a growing awareness, it potentially opens up new situations each time.

The concept of self and contact as a primary reality in Gestalt therapy, which was created in the 1950s, seems to be more tailored to today's times, especially with the most recent, thorough theoretical additions indicated above. In the mainstream of sociology, two mutually exclusive epistemological currents have dominated in recent decades, to put it very mildly. As will be demonstrated, their contradictory nature couples them with almost unchanging persistence, and in this sense they are inflexible (in use) and reflect the nature of contemporaneity unilaterally (each in a different way). Such disjointing has continued since the 1960s and 1970s: on the one hand, we are dealing with a wave of slogans about freedom, individualism, and the negotiability of the social order from the perspective of individual actors, which in the social sciences is reflected by the interpretive turn. On the other hand, this tendency has met with fierce criticism and a so-called wave of disenchantment, which in the social sciences derives from critics of capitalism, the Frankfurt School, and so forth. The 1980s and 1990s saw a certain degree of repetition of the process: there was an intensification of the rhetoric of subjectivity and participation, with a parallel focus in the social sciences, while there was also criticism (a critical or deconstructive standpoint), which in sociology was mainly inspired by the Marxist tradition and the new phenomenon of governmentality studies.

Such disjointing of the above tendencies reflects the dualistic epistemology behind them: the self is in confluence (in a state of indistinctness) with the world, absorbed by this world through characteristic introjects (freedom, etc.), or the self is in a state of egotism (isolation and confinement in the self's mind) in regard to the world (one that is alienating on its own), as represented in social science by critical or deconstructional attitudes. ${ }^{1}$ It follows that the "I" is either confused about reality or is withdrawing from it and judging it from a distance.

\footnotetext{
${ }^{1}$ In the Gestalt therapy approach there are so-called mechanisms of contact interruption. More recently, the mechanisms are seen as a relational process and the emphasis is on the quality of contacting. The confluence and egotism of interest to us in this article present opposite difficulties. In their least creative manifestations, egotism is a fixed "I" whereas confluence is a deficient, indistinct, or non-differentiated "I".
} 
Is there a third way? New trends of organisation and management promoting "empowerment", "creativity", and so forth, while repeating typical themes from the criticism of capitalism in the 1960s, quickly turned out to be just more incarnations of the ideology that was criticised by the wave of governmentality studies, as discussed in the article on hypermodernity. The concept of a "third way" is only an illusionary way out of the epistemological impasse. These processes are in collusion with each other; they are mutually dependent and thus perpetuate the invariability of the social order and the respective conformist and/or withdrawal attitudes in society. In the aforementioned article-with reference to the strategies our narrators take-we have described attitudes of "rebellious" conformism (hypermodern cyclothymia) and "conformed" rebellion (hypermodern distance) ${ }^{2}$

The non-dualistic epistemology used to describe and analyse the postmodern order, rather than any other order, may provide a perspective for overcoming the impasse. Unlike in the hypermodern order, postmodern actuality goes beyond the dualism of the individual and society, containing both the confluence of dependency and the rebellion against it, where individuals are the cause of their own actions and must realise themselves whether they want to or not, yet they are individualistically networked. In their book on the transformation of social bonds, Marody and Giza distinguish between contemporaneity and postmodernity: between interactions and bonds based on the (felt) sense of relationality, as well as between arbitrary will and reflective will, and last but not least, between the break in the common weal and being in relationships with other regional or local communities (Marody, Giza-Poleszczuk 2004).

Hypermodernity is characterised by an ideology of free will and individualism, but in fact identity is heavily dependent on work; identity is either weak and ideologised, or weak and defensive against this ideology, for which a large part of life energy is devoted. From a psychological point of view, self-realisation is possible when the so-called separation anxiety is overcome (Rank 1932); the types of hypermodern patterns illustrated very clearly indicate dependence (no separation) on the sphere of work, including withdrawal, or passiveness, or distance from corporate workthese attitudes are reactive and thus indicate the subordination of identity to the sphere of work (and not, as the narrators try to convince themselves, the other way round).

2 It seems the categories "hypermodern confluence" and "hypermodern egotism" could also be applied in this case. 
In postmodernity, however, the separation anxiety is considerably reduced, which is associated with an increasing concentration on reflectiveness (strengthened by the increasing importance of therapy culture, with its narcissistic but also deconstructive aspect) and to some extent the resulting reflexivity (an increasing awareness of being in the world with others, not only in the form of the ideology of community, but also -if not most importantly-with an acknowledgement of the relational nature of all phenomena, including their co-emergence and co-creation). This means that unlike in hypermodernity, the individual theme in postmodernity is linked to the social. Moreover, as will be demonstrated, conformism is linked to withdrawal and confluence with egotism, and both these aspects of communication or existence are not mutually exclusive here. As has been said before, postmodern actuality consists of both. Again, Marody and Giza-Poleszczuk suggest there are two models of identity distinction typical for contemporaneity and postmodernity: between $\mathrm{I} /$ they and I/we.

The concept of the self and the world field in the epistemology of Gestalt therapy makes it possible to go beyond the dualism of the individual and society, without losing a contextual view, the location of phenomena, or events and processes. However, there is a difference between describing some interaction between the self and the world, and the interactive self-world set (Wollants 2008). The perspective of field theory is non-dualistic, in which the self and the world are functions of the field. When we describe the situation from the perspective of the context, we focus on separate elements interacting. From the perspective of field theory, we reflect on the situation as a situation co-created here-and-now-one that is a function of a given field, although this does not mean that we ignore the history of the elements in that field (Roubal, Gecele, Francesetti 2017: 123).

Recently in sociology we have encountered a very similar-most probably through its direct and significant references to phenomenologyperspective of the self and world relationship and the related resonance concept (Rosa 2016). ${ }^{3}$ Resonance as the basis for another epistemology assumes going beyond the aforementioned impasse between consonance (confluence) and dissonance or alienation (egotism), and responding anew each time (subjective functioning) to what has previously been experienced (objective functioning). To resonate in the model approach is

${ }^{3}$ Contemporary philosophy and neuroscience are addressing this phenomenon of the field as well. Generally speaking, the focus of the study is on the unitary feeling that precedes the differentiation of perception and thoughts (Fuchs 2017; Gallese 2014). 
therefore neither to merge nor to isolate, but to listen, to get involved, to let oneself be experienced ( $\mathrm{af} \leftarrow$ fection, alien to the ego), and to respond critically (e $\rightarrow$ motion, move out). Thus, consonance and dissonance coexist and are in constant motion, resonating in the world, from engagement to criticism, from criticism to engagement, and are not disjoined.

In the postmodern order, if the involvement of individuals enters the phase of non-separation or confluence, it has the potential to shift into distinctiveness, which does not have to be escapist, and in the criticism phase, even if is isolating, it can smoothly take practical shapes and be included in the world, in a network of relations with others. The self-world relation is therefore assumed here; the implication is not necessarily optimism, but rather a certain realism, and at times an overwhelming necessity: resonance as a synonym for a primary or basic entanglement in the world. It is not only an assumption, a tacit knowledge, but also something subject to experiencing and reflection, something set in motion, which is a keystone of the most vital issues of individuals in postmodernity.

To return for a moment to the Gestalt psychotherapy theory, it is in this phenomenological process of organising experience that the self arises, changes, and becomes a dynamic organisation of its subjective and objective aspects, experienced alternately as a figure or background and not stuck on the confluent "we" or in the egotic "I." From this process of contacting or resonating, the (relational) awareness or consciousness and subjectivity is created; the whole world of the individual emerges, reorganises, and its relation to the individual's self, other people, the individual's own activity, and abstraction - that is, certain fixed elements-are formed. In other words, in this shift from confluence to egotism, there are stability and variability, permanence and change, two inseparable-in a natural sense-components of the process of constituting the social world.

\section{EMPIRICAL EXAMPLES}

For this research project, the epistemology discussed here was used as a certain hermeneutical tool for understanding those of our narrators' life stories that exhibit the most postmodern traits (in the sense of the term developed here), and later also for understanding the process by which the subjectivity and biographies of individuals were formed in the context of post-transformation Poland. However, the interviews were not intentionally designed or conducted according to this epistemology.

The two typical-and in our opinion, postmodern-models of life which we will present below and describe as postmodern confluences and 
egotisms, are not pure and unproblematic examples. Both narrators, despite their awareness of being in the world and the relatively high energy they bring to being active in it, make themselves solitary and alienated. They each function in a paradigmatically different way, but are similar in the sense of having high energy levels, which, if not supported by the environment, would probably be difficult to bear, especially in the context of the hypermodern corporate order. They do not make this the subject of their reflections (either in life or as metareflection in the interview), but in both narratives traces of "slipping down" into defensive or reactive strategies can be seen, either in the form of too much fluid confluence (cf. Jagoda's case below) or too much fixed egotism (Janek's case below). These are hypermodern cyclothymias and distance, respectively.

Postmodern confluences reflect a more natural transition and oscillation between the poles of engagement and withdrawal than the examples of narration that often follow a trajectory, which we have described elsewhere as hypermodern cyclothymias. Here, stability is not-as in cyclothymias - the main theme. The merging with some situations, actions, and people is not only casual and point-based, but also ephemeral. People are just as likely to withdraw from a given engagement as to open themselves (enthusiastically) to new ones. More is concerned than solely specific phases of life; it is also difficult to define a guiding theme, apart from the one resulting from personal and often hedonistic motives to get involved to the limits of the "I" or beyond. However, even if the need for (the persistence in) confluence (with a particular introject) quickly becomes central, the individuals' first impulse is to look for their own distinctiveness, which usually concerns identity. The same reflex, in spite of its often hedonistic nature, makes this involvement critical. However, such involvement does not lead to permanent conformism; in contrast to the narratives described as hypermodern distance, individuals' fear of realising their identity inclinations is lessened and does not cause a withdrawal (and compensation). Nevertheless, it is an exploitation model in the given external conditions of the modern world, and some of the interviews we have collected include biographies in which it is evident that the narrator withdraws from this path towards various types of normalisations, such as the modern family.

From the very beginning, Jagoda's life is characterised by a search for close relationships with people, individuals, and groups, in which she can fully immerse herself. During her adolescence she had a strong bond with a friend, and together they went through a highly risky phase of rebellion (drinking, running away from home, etc.). She also had a tie with 
the local music community, which invited well-known bands to the city (Jagoda, despite her young age, intensively participated in the life of this circle and stayed with the musicians late into the night). After a turbulent period of studies (let us add that she talked about her field of study with great enthusiasm during the interview), she unexpectedly met a foreigner and followed him abroad, leaving her boyfriend here (as she recalls, the relationship had clearly burned out by then). She and the foreigner got married abroad, but the marriage did not go well. He used drugs; she initially accompanied him, but at some point she wanted to stop. She enrolled in school abroad, in order to study what interested her, and finally, thanks to new contacts, she was able to get out of the relationship and, after several years, come back to Poland. There, at the instigation of her friend, she started working in a democratic school (where she was very happy at first), and met a new partner quite quickly, but the following years gradually brought frustration, both at work (despite the school's ideological profile, which was important to her, she had an authoritarian boss with whom she did not get along) and in the relationship (apart from their shared interests in music and a fondness for various stimulants, they had little in common, as Jagoda realised after some years). She decided to start a training school for teachers in another city, where she had been commuting for a couple of years. Consequently, she was able to leave her job, and it was while attending the new school that she met her current partner, for whom she moved again to another city and with whom she is now living. On the other hand, she works for a second consecutive corporation, and at the time of the interview she was thinking about leaving that job and founding an association at the existing democratic school, co-run by a circle of friends she met here and who have become close to her.

Despite the fact that Jagoda has been absorbed many times in her life, each time she demonstrates agency in order to overcome a specific dependence. She has never had a biographical plan, nor does she look for stability; she has realised herself in various activities that came her way, but also in ones that she devised for herself. She has not been overly concerned about the assessment of others, nor about status problems-the promotions or downgrading in subsequent jobs-while local trajectories were manageable for her. Although engaging time and again in different areas is, by its very nature, objectifying, her narrative does not create a sense of void. However, at various moments of her biography, after intense involvement in some activity, she "slipped down" (confluently) and egocentrically closed into relations with men that quickly became toxic. She was able to 
recover from them, but it is difficult to assess the credibility of her social involvement and hence the strength of the "I."

Postmodern egotisms as models of life shift the emphasis from critical engagement to engaged criticism. The project of oneself is the result of criticism of reality, as it appears to the narrators, and then there is commitment to change the world that makes up the individual identity. While postmodern confluences are more indicative of "qualities without a man" (to paraphrase title of Robert Musil book on "The Man without Qualities")—that is, a project of oneself that is to a large extent inconsistent, multifrenic, and sometimes even void-postmodern egotisms can be characterised as relatively coherent projects, resulting from criticism that engages in the world. However, there are examples of biographies in which critical or egotic potential dominates over participatory or confluent potential to such an extent that the narrators have difficulty finding themselves in the world and in social relations, and to a large extent make themselves solitary with their low-inclusive critical projects.

Janek has been acquainted with corporate life since his graduation from university (he studied political science). He has worked as a freelancer on various advisory projects. From the outset, however, this has merely been a means of making a living, and his narrative is dominated by the struggle for a better world, and, as we will see, by undermining various friendship, environmental, and professional contexts in this respect. Thus, in his efforts to make a fairer world a reality in these different circles, he knows that he also wants an answer to the question of his role in these processes. He started training in psychotherapy, partly in response to work in a corporation and hence the search for another source of financing, but above all because of his concept of himself and the world in which he wants to live. He quickly established various relationships, both with students and teachers, because of his activist and collectivist attitude: he began to organise various social initiatives within and outside the school (quite spectacular initiatives, and some of them have become traditions), but he also clashed with some people just as quickly. As he himself admits, the conflicts were partly due to his need to reconfigure the world (in which he is currently involved), manifested by a heightened need for control, which leaves little room for the creative or authentic contributions of others. This is largely due, he believes, to his long-standing struggle with anorexia. In addition to the need for control that results from it, Janek also exhibits significant victim syndrome and the connection between a sense of hurt and embarrassment which is characteristic of this complex. In relationships, this results in a certain degree of withdrawal and isolation, especially as 
his uncompromising attitude pushes people away from him over a longer period of time. As a result, in a situation where the environment provides little support, he still needs to push himself and his actions in order to maintain his aspirations. It seems that in his involvement in the world not only is there more egotism than confluence but it may also partly be compensatory (resulting from deficits), which undermines his credibility and, above all, his agency, because the said need to change the world resembles to some extent the compulsion to control and to isolate that is a precisely fixed egotism. Janek realises this, but he still finds it difficult to confront and work through his relational problems: he has interrupted his therapy several times; he gets involved mainly in long-distance relationships; he does not have long-term close friendships.

\section{CONCLUSIONS}

In this article we wanted to present postmodern biographical strategies within the corporate order in the lives of the narrators of interest to us. In order to understand and analyse the nature of these processes, we used a specific non-dualistic hermeneutics. Its application allowed us to broaden our initial understanding of postmodernity and postmodern subjectivity. An important category has been resonance and thinking about postmodernity as a growing awareness of our (us-individuals) resonance in the world, which is entangled in relations with others, and about the primariness of this entanglement or resonance and thus its properties that are constitutive for the social world.

During this series of interviews, we have paid particular attention to those interviewees characterised by a high level of activity and flexibility and only minor manifestations of the resort to various compensation or normalisation strategies familiar to us from other interviews. We have assumed that since postmodernity, in its adventitious and changeable nature, inevitably refers us to identity as the only certainty, the processes of reflectiveness and reflexivity-gradually and in certain contexts in particular-have to go beyond or rework the compensatory, narcissistic, and hypermodern strategies that characterise late capitalistic society.

It emerged that with such growing relational awareness and subjectivity, individuals like those in this article are characterised less by fear, separation anxiety, or fear of self-realisation, and more by aggression: an ego aggression implying the need for contact with the world (as opposed to the hypermodern ego defence that in many cases leads to neoliberal agency), which makes it possible to oscillate smoothly between the po- 
larities of fusion and isolation, engagement and criticism, duration and change-that is, to resonate.

\section{REFERENCES}

Bloom, Dan. 2009. "The phenomenological method of Gestalt therapy: revisiting Husserl to discover the essence of Gestalt therapy." Gestalt Review 13 (3): 277-295.

Francesetti, Gianni. 2016. "The emerging, co-created self as the foundation of anthropology, psychopathology and psychotherapy in Gestalt therapy.” J.-M. Robine (ed.). Self: A Polyphony of Contemporary Gestalt Therapists. St. Romain la Virvée: L'Exprimerie.

Frank, Ruella. 2016. "Self in motion." J.-M. Robine (ed.). Self: A Polyphony of Contemporary Gestalt Therapists. St. Romain la Virvée: L'Exprimerie.

Fuchs, Thomas. 2017. Ecology of the Brain: The Phenomenology and Biology of the Embodied Mind. Oxford: Oxford University Press.

Gallese, Vittorio. 2014. The Birth of Intersubjectivity: Psychodynamics, Neurobiology, and the Self. New York: W. W. Norton.

Marody, Miroslawa, Anna Giza-Poleszczuk. 2004. Przemiany więzi społecznych. Warszawa: Wydawnictwo Naukowe PWN.

Perls, Fritz, Ralph Hefferline, Paul Goodman. 1951. Gestalt Therapy: Excitement and Growth in the Human Personality. Highland: Gestalt Journal Press.

Rank, Otto. 1989 [1932]. Art and Artist: Creative Urge and Personality Development. New York: W. W. Norton.

Rosa, Hartmut. 2016. Resonanz. Eine Soziologie der Weltbeziehung. Berlin: Suhrkamp.

Roubal, Jan, Michela Gecele, Gianni Francesetti. 2017. "Diagnoza w psychoterapii gestalt." Gianni Francesetti, Michela Gecele, Jan Roubal (eds.). Psychoterapia gestalt w praktyce klinicznej. Od psychopatologii do estetyki kontaktu. Gdańsk: Harmonia Univeralis.

Spagnuolo Lobb, Margherita. 2011. The Now-for-Next in Psychotherapy Gestalt Therapy Recounted in Post-Modern Society. Milan: Instituto di Gestalt.

Wollants, George. 2008. Gestalt Therapy: Therapy of the Situation. London: Sage.

\section{Abstract}

In this article the author intend to use an epistemological concept and its categories of description to analyse two specially chosen biographies reflecting diverse postmodern life patterns. Postmodernity, or in fact the postmodern order, refers to the concept of order-making dimensions discussed in the previous article concerning hypermodernity. It is treated there as casual and variable with regard to the category of relations and work, and the only certainty for the individual, in regard to future possibilities or necessities, is the individual's own identity. This article adds the category of resonance to the characteristics of postmodernity, as a synonym for a person's primary entanglement in the world. It is a category of which individuals are increasingly aware, on which they reflect, and which they make an object of their experience. 
Key words: postmodernity, transnational corporations, relational epistemology, resonance, biography

\title{
PONOWOCZESNOŚĆ KORPORACYJNYCH BIOGRAFII. PERSPEKTYWA RELACYJNEJ EPISTEMOLOGII
}

\author{
Kamila Biały \\ (Uniwersytet Łódzki)
}

\begin{abstract}
Abstrakt
W artykule do analizy dwóch biografii reprezentujących różnorodne ponowoczesne wzorce życia została zastosowana szczególna rama epistemologiczna i jej wybrane kategorie. Ponowoczesność, a właściwie ponowoczesny porządek jest traktowany jako swobodny i zmienny w odniesieniu do kategorii więzi i pracy, podczas gdy jedynym źródłem pewności dla jednostki jest ona sama i jej tożsamość, niezależnie od tego, czy jest to wariant jej przyszłych możliwości czy potrzeb. Taka charakterystyka ponowoczesności zostaje rozszerzona o kategorię rezonansu jako synonim pierwotnego/podstawowego uwikłania w świecie. Rezonansu tego jednostka jest coraz bardziej świadoma, zastanawia się nad nim i czyni/musi uczynić obiektem swojego doświadczenia.
\end{abstract}

Stowa kluczowe: ponowoczesność, korporacje transnarodowe, epistemologia relacyjna, rezonans, biografia 